\title{
AN ANALYSIS OF THE INTERNATIONAL SCIENTIFIC PRODUCTION ON CONTEMPORARY MARKETING PRACTICES
}

ANÁLISE DA PRODUÇÃO CIENTÍFICA INTERNACIONAL SOBRE PRÁTICAS CONTEMPORÂNEAS DE MARKETING

\author{
Aléssio Bessa Sarquis \\ E-mail: alessio.sarquis@gmail.com \\ Programa de Pós-Graduação Mestrado em Administração da Universidade do Sul de Santa Catarina (UNISUL), Florianópolis, SC - Brasil \\ ORCID: http://orcid.org/0000-0001-9690-0510
}

\section{Lenoir Hoeckesfeld \\ E-mail: leno.adm@gmail.com \\ Instituto Federal de Mato Grosso (IFMT), Alta Floresta, MT - Brasil \\ ORCID: https://orcid.org/0000-0002-1339-1157}

\section{Jacir Favretto}

E-mail: jacirfa@gmail.com

Programa de Mestrado Profissional em Administração da Universidade do Oeste de Santa Catarina (UNOESC) - Joaçaba, SC - Brasil ORCID: https://orcid.org/0000-0001-7530-8016

\section{Eric David Cohen}

E-mail: ericdcohen@gmail.com

Mestrado em Governança Corporativa do Centro Universitário das Faculdades Unidas Metropolitanas (FMU), São Paulo, SP - Brasil ORCID: https://orcid.org/0000-0003-0994-1731

\begin{abstract}
Contemporary marketing practices entail strategies such as customer relationship, interactive marketing, big data and digital marketing, going beyond traditional tactics. We conducted a bibliometric study of the international scientific production through 2016 to provide an update of the advances in the field, and developed a documentary survey for this exploratory and descriptive study using a qualitative and quantitative approach. The content analysis and thematic categorization identified 42 articles by 101 authors from 49 universities and 23 countries, and twelve small groups of authors. The average output is wanting, though works such as Coviello et al. (2002) are considered highly relevant. The study shows that contemporary marketing practices research is predominantly empirical, qualitative and exploratory; data collection occurs through surveys, in-depth interviews and documentary analysis. The study's theoretical contribution and academic relevance stem from the definition of the characteristics of extant research, and by the research agenda for future studies.
\end{abstract}

Keywords: Marketing. Contemporary marketing practices. Scientific production. Bibliometric analysis;

\section{Resumo}

As práticas contemporâneas de marketing abarcam estratégias que transcendem as táticas tradicionais, como o relacionamento com clientes, marketing interativo, big data e marketing digital. Este artigo atualiza seus avanços pela análise bibliométrica da produção científica internacional até 2016, tendo enfoque qualitativo e quantitativo, e caráter exploratório e descritivo. O levantamento documental e análise de conteúdo com categorização temática apontam para 42 artigos alinhados com o tema, provenientes de 101 autores, 49 universidades e 23 países. Existem doze redes com poucos pesquisadores; a média anual de publicações é baixa, mas há estudos altamente relevantes (Coviello et al., 2002). Predominam estudos empíricos, qualitativos e exploratórios; os métodos de coleta mais utilizados são surveys, entrevistas em profundidade e levantamento documental. A principal contribuição teórica é a caracterização da produção científica internacional, e a relevância acadêmica se dá com a proposição de uma agenda de pesquisas.

Palavras-chave: Marketing. Práticas contemporâneas de marketing. Produção científica. Análise bibliométrica. 


\section{Introdução}

Since 1996, the marketing field began to formally investigate the Contemporary Marketing Practices (CMP) as a subject for inquiry, through the initial stimulus from the research group comprised by Brodie and Coviello, from the School of Business Administration University of Auckland, New Zealand (BRODIE; COVIELLO; WINKLHOFER, 2008). In this regard, Wilkie and Moore (2003) posit that marketing began to develop as a field of knowledge in the 20th century, with four development stages: Founding the Field, from 1900 to 1920; Formalizing the Field, from 1920 to 1950; A Paradigm Shift-Marketing, Management, and the Sciences, 1950 to 1980; and The Shift Intensifies-A Fragmentation of the Mainstream, 1980 to present.

The CMP conceptual framework extends the strategies and actions from the traditional marketing mix (popularly known as the 4P's). It encompasses customer relationship marketing management, network marketing, experience marketing, digital marketing, human-centered marketing and marketing innovation, among other topics in the field (O'DWYER; GILMORE; CARSON, 2009; SACRAMENTO; TEIXEIRA, 2014).

According to Shaw and Jones (2005), in the early 20th century, marketing evolved from individual concepts to schools of marketing thinking. CMP scholars claim that traditional marketing theories do not efficiently describe the current organizational practices. This is particularly the case of companies that operate in the service sector (REID, 2008; REIJONEN, 2010). For these authors, the modern competitive environment imposes demands on the organizations, such as the adoption of informal practices and interactive communication mechanisms. According to them, the contemporary actions help strengthen long-term strategic relationships with clients and stakeholders, in comparison with the traditional orientation, which focuses on transaction-based sales. Reid (2008), for example, posits that the survival of professional service organizations depends critically on the quality of the relationships with relevant clients and stakeholders.

Ten years after the publication of the seminal work of Coviello, Brodie and Munro (1997), this survey searched the Business Source Complete (EBSCO), SCOPUS / Elsevier, Spell / Anpad and Google Scholar databases and found one single CMP paper from Brodie, Coviello and Winklhofer (2008) of an empirical investigation in 15 different countries. The work broadened the academic knowledge of the strategies used by companies in their relationship with the market, suppliers, customers, employees and other business partners. The authors describe the connections between traditional marketing theories and contemporary practices from an organizational perspective.

In this context, a new bibliometric study on the CMP is well justified, since the last research on the topic occurred ten years ago. There is a critical need to update the knowledge of the evolution of the contemporary marketing practices, by looking at the research methods used and the research gaps that may still exist, and direct new studies in the field. The bibliographic survey describes, organizes and analyzes the extant research (GUEDES; BORSCHIVER, 2005). Lastly, by following Mazzon and Hernandez's (2013) recommendations in terms of providing evidence of academic performance, a survey of scientific CMP production will help academia in producing research evaluation criteria.

In view of these questions, we state the research problem as follows: what are the characteristics of the international scientific production on contemporary marketing practices, published through 2016? Accordingly, the general objective is to analyze the characteristics of the international CMP scientific production, as found in publications from the EBSCO, SCOPUS, Spell / Anpad and Google Scholar databases in the period that extends until December 2016. Specifically, we aim to identify the articles, authors, keywords, scientific journals and universities with the largest scientific production; to identify methodological choices in CMP research; and to propose a research agenda on the contemporary marketing practices, based on our findings.

This research provides a significant contribution to the scientific knowledge in the field, as it relates to the contemporary marketing practices of organizations, since it describes the state of the art 
and the characteristics of the extant research. In addition, it presents criteria for the evaluation of scientific research that may be used by academia and institutions with an interest in the subject. In addition, by stimulating further scientific development, it lays out a research agenda for the subject and identifies theoretical gaps in the field.

\section{Literature Review}

\section{Contemporany Marketing Practices}

According to O'Dwyer, Gilmore, and Carson (2009) and Sacramento and Teixeira (2014), the marketing literature contains a stream of research on Contemporary Marketing Practices which investigates modern marketing practices - specifically, facets of customer relationship management, network marketing, marketing innovation, digital marketing, and self-centered marketing human, among other topics. Brodie and Coviello's (1997) broadened the understanding of the relationship between the firm and the market, and examined the relevance of marketing practices in different organizations (BRODIE; COVIELLO; WINKLHOFER, 2008).

In a subsequent theoretical development, Coviello, Brodie and Munro (1997) and Coviello, Milley and Marcolin (2001) defined a CMP conceptual model that contains five dimensions. The model can be interpreted as a marketing shift from the transactional (i.e. transaction-based) to the relational (relationship-based) perspective. Ekman, Erixon and Thilenius (2015) note that the transaction-based marketing approach still dominates the marketing organizational scenario. Table 1 describes these marketing approaches from a relational perspective.

According to Ekman, Erixon and Thilenius (2015), the transaction-based perspective favors short-term economic transactions and the development of impersonal and formal relationships with a group of potential buyers - which they dubbed "mass market". The first dimension of this conceptual model comprises the transaction marketing, which focuses on the acquisition of new customers, and prioritizes business potential and meeting customer needs. However, this perspective centers on the organization's profitability, and uses the elements of the traditional marketing mix. 
Table 1 - Dimensions and marketing approaches in the relational perspective.

\begin{tabular}{|c|c|c|c|c|c|}
\hline & Characteristics & Database Marketing & Digital Marketing & Interactive Marketing & Network Marketing \\
\hline \multirow{5}{*}{ 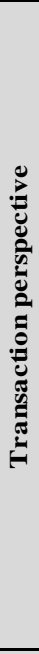 } & $\begin{array}{l}\text { Objective of the } \\
\text { transaction }\end{array}$ & $\begin{array}{l}\text { Information and economic } \\
\text { transaction }\end{array}$ & $\begin{array}{l}\text { Dialogue generates exchange } \\
\text { of information from the } \\
\text { salesperson and many other } \\
\text { identifiable customers }\end{array}$ & $\begin{array}{l}\text { Interpersonal relations } \\
\text { between buyer and seller }\end{array}$ & $\begin{array}{l}\text { To obtain relationships with } \\
\text { other companies and } \\
\text { organizations }\end{array}$ \\
\hline & $\begin{array}{l}\text { Nature of the } \\
\text { communication }\end{array}$ & $\begin{array}{l}\text { From the company to market } \\
\text { segments or specific } \\
\text { customers }\end{array}$ & $\begin{array}{l}\text { Use of technology to } \\
\text { communicate with or within } \\
\text { groups and individuals }\end{array}$ & $\begin{array}{l}\text { Individuals with Individuals, } \\
\text { in different units and areas of } \\
\text { the organization }\end{array}$ & $\begin{array}{l}\text { Business to business } \\
\text { (involving individuals) }\end{array}$ \\
\hline & Type of contact & Customized (but distant) & $\begin{array}{l}\text { Interactive (through } \\
\text { technology) }\end{array}$ & $\begin{array}{l}\text { Face-to-face, interpersonal } \\
\text { and with proximity, based on } \\
\text { commitment, trust and } \\
\text { cooperation }\end{array}$ & $\begin{array}{l}\text { Impersonal e interpersonal (in } \\
\text { person or distant) }\end{array}$ \\
\hline & Duration & Occasional and long term & $\begin{array}{l}\text { Continuous and with on-line } \\
\text { interactivity }\end{array}$ & $\begin{array}{l}\text { Continuous and mutually } \\
\text { adapted, in the short or long } \\
\text { term }\end{array}$ & $\begin{array}{l}\text { Continuous, stable and } \\
\text { dynamic, can be short or long } \\
\text { term }\end{array}$ \\
\hline & Formality & $\begin{array}{l}\text { Formal (customized by } \\
\text { technology) }\end{array}$ & $\begin{array}{l}\text { Formal (customized and/or } \\
\text { personalized through } \\
\text { interactive technology) }\end{array}$ & Formal and informal & Formal and informal \\
\hline \multirow{4}{*}{ 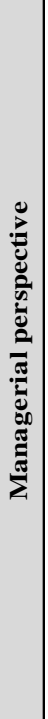 } & $\begin{array}{l}\text { Management } \\
\text { objective }\end{array}$ & $\begin{array}{l}\text { Customer retention, customer } \\
\text { satisfaction, profitability and } \\
\text { loyalty increase, reduction of } \\
\text { customer risk) }\end{array}$ & $\begin{array}{l}\text { Creation of dialogues by } \\
\text { information technology }\end{array}$ & $\begin{array}{l}\text { Establish and develop } \\
\text { customer interactions, } \\
\text { facilitating the cooperative } \\
\text { relationship and mutual } \\
\text { benefits }\end{array}$ & $\begin{array}{l}\text { Coordinates interaction } \\
\text { between salespeople, buyers } \\
\text { and other professionals from } \\
\text { different companies, with the } \\
\text { intent of obtaining mutual } \\
\text { benefits) }\end{array}$ \\
\hline & Management focus & $\begin{array}{l}\text { Product/brand and clients (in } \\
\text { a target market) }\end{array}$ & $\begin{array}{l}\text { Relationship management } \\
\text { between the company and the } \\
\text { multiple individuals through } \\
\text { information technology }\end{array}$ & $\begin{array}{l}\text { Relationships between } \\
\text { individuals }\end{array}$ & $\begin{array}{l}\text { Network relationships with } \\
\text { other companies and } \\
\text { organizations }\end{array}$ \\
\hline & $\begin{array}{l}\text { Management } \\
\text { investment }\end{array}$ & $\begin{array}{l}\text { Internal marketing assets } \\
\text { (emphasis on the } \\
\text { communication, information } \\
\text { and technology capabilities) }\end{array}$ & $\begin{array}{l}\text { Internal operational assets } \\
\text { (IT, website, logistics); } \\
\text { integration of functional } \\
\text { systems }\end{array}$ & $\begin{array}{l}\text { External market assets (focus } \\
\text { on the establishment and } \\
\text { development of relationships } \\
\text { with other individuals) }\end{array}$ & $\begin{array}{l}\text { External market assets (focus } \\
\text { on the development of the } \\
\text { company's position in the } \\
\text { relationship network) }\end{array}$ \\
\hline & Management level & $\begin{array}{l}\text { Marketing specialists (e.g. } \\
\text { customer service manager, } \\
\text { customer portfolio manager) }\end{array}$ & $\begin{array}{l}\text { Marketing specialists with IT } \\
\text { specialists and senior } \\
\text { managers }\end{array}$ & $\begin{array}{l}\text { Employees and managers } \\
\text { (from all areas and functions, } \\
\text { and hierarchical levels in the } \\
\text { company) }\end{array}$ & Senior management \\
\hline
\end{tabular}

Source: Coviello, Brodie and Munro (1997); Coviello, Milley and Marcolin (2001).

In this context, marketing activities typically occur within the scope of the marketing functions. Management (i.e., the sales manager or brand manager) are either product or brand oriented and tend to focus on the development of internal marketing capabilities and assets - such as products, distribution channels and promotional efforts. At the same time, salespeople focus on the processes in which the customer exchanges take place - in other words, they seek closure, timely transactions and communication with potential buyers (COVIELLO; BRODIE; MUNRO, 1997; COVIELLO; MILLEY; MARCOLIN, 2001).

On the other hand, the relational perspective focuses on the development of relationships with clients or other stakeholders that are deemed to be highly relevant. This approach favors the development of long-term, continuous, interactive, close and personalized relationships (COVIELLO; BRODIE; MUNRO, 1997; COVIELLO; MILLEY; MARCOLIN, 2001).

The second approach uses database marketing, defined as the use of information technology techniques and tools to gain information, win businesses, develop relationships, and keep active the valuable customer relationships. This approach holds the following properties: the infrastructure is developed to capture customer information and purchase transactions; the company targets 
communications to its market segments, or groups of specific customers; the communications between the company and the customer are not so interactive and are distant; and the customer service is formal, customized only by technology (COVIELLO; BRODIE; MUNRO, 1997; COVIELLO; MILLEY; MARCOLIN, 2001).

Paas (2009) studied the use of database marketing practices in the banking, insurance and mobile telephone industries. In his work, the author draws the attention to hurdles that arise from its application; specifically: difficulty in accessing customer information; investment requirements for data warehouse infrastructure; and lack of specialized knowledge to use the available data. Another study worth mentioning is Gregurec, Vraneevi, and Dobrini (2011): these authors consider the importance of combining advertising tactics with database marketing and social networks to boost marketing productivity, and help develop meaningful customer relationships, which in turn leads to competitive advantage. In addition, the authors suggest that companies that use database marketing tend to enjoy a higher level of customer trust, and are therefore more prone to develop relationships more quickly and profitably.

Digital marketing is another form of a relational approach, which uses the Internet and other interactive digital technologies to create dialogues between the company, its customers and other stakeholders. According to El-Gohary (2010), this approach uses technology and the Internet (i.e.: IT, website and logistics) to promote and sell products, as well as to communicate relevant messages to the consumer constituency. Digital marketing supports the business activity by establishing a relevant dialogue between sellers and consumers; it helps companies obtain relevant information; it is used for enterprise communications based on digital technology to target specific customer groups; the firm's services tend to be formal; it fosters business contacts through Internet interactivity on a continuous basis; and it allows personalized relationships through the use of technology.

In a digital marketing study, Brodie et al. (2007) confirmed that $70 \%$ of the companies surveyed use database marketing tools at a moderate or high level. In addition, they found a prevalence of these tools in B2B (business to business) companies when compared to B2C (business to consumer) settings. The authors also conclude that it is common for digital marketing to be integrated with other marketing practices, and found a strong relationship between the use of digital marketing and the company's performance, customer retention and loyalty. Conversely, Nobre and Silva's (2014) study of small and medium-sized companies reveals that digital marketing facilitates the communication with customers, brand recognition and awareness.

The theoretical model posited by Coviello, Brodie and Munro (1997) and Coviello, Milley and Marcolin (2001) also includes interactive marketing (defined as the set of actions directed to the development of interpersonal relationships with clients and other stakeholders by use of technological techniques and tools). The model presumes a strong employee participation from various functional areas to develop close relationships and promote customer loyalty. The main characteristics of interactive marketing are: the company's communications are individualized and interactive; they are characterized by face-to-face, personal, close and on-going contacts; it stimulates commitment, trust and cooperation; service processes can be both formal and informal; and the customer plays an active role in the production and delivery of service.

Along the same lines, Wagner (2005) propose that organizations that invest in interactive marketing tend to enjoy stronger and more loyal customer relationships than their competitors. This is due to the close and intimate links with the consumer. According to Lado, Duque and Alvarez Bassi (2013), contemporary interactive marketing practices comprise the development of long-term relationships; cooperative customer efforts; personalized and interactive contacts; and investing in the customer acquisition and maintenance. The authors developed a study of small companies of consumer goods and services, and found a strong relationship between the practices of database marketing, interactive marketing and network marketing, which corroborates Coviello et al.'s (2003) propositions. 
Lastly, network marketing is defined as the participation in networks of other organizations (such as an institutional agreement with other companies), or individuals (such as the relations of owners or managers of the network company), with the intent of securing resources, knowledge, business, access to markets and social and business contacts. According to this concept, the company builds relationships with potential clients, suppliers, competitors, business agencies, state companies and employees, among others (O'DONNELL, 2004); in this context, the company focuses on: building relationships with other companies or organizations; directing communications to individuals through impersonal and interpersonal contacts, on a continuous, stable and dynamic basis; and processes are considered formal or informal.

Menelec and Jones (2015) postulate that the network marketing practices also occur within community entities, business partners and government agencies. According to the authors, several benefits arise from this approach, namely: partner commitment and greater client trust; seamless exchange of marketing information; and opportunities for brand promotion. Along the same lines, Rogan and Mors (2016) research posits that managers tend to gain more knowledge and information, which in turns leads to superior business performance. Companies follow these marketing network practices have greater autonomy, take better advantage of market opportunities, and have a wider array of contacts to leverage resources.

The research by Centeno and Hart (2012) and Ekman, Erixon and Thilenius (2015) confirms that managers increasingly emphasize the relationship management with employees, suppliers, customers and business partners. The authors also note that some organizations seek to develop interactive and personalized customer contacts that yields benefits to the concerned stakeholders. These organizations typically use transaction marketing, databases, digital marketing, interactive marketing, and network marketing practices.

Our survey of the international CMP studies indicates that most of the research still demands an understanding of the organizational marketing practices in different sectors and branches of activity. It also shows a predominant use of qualitative approaches. Since 2008, researchers from different countries, such as Canada, Finland, Holland, Germany, Ireland, Spain, Russia, Thailand, Malaysia, Ghana, Ivory Coast, China and Australia have been making headway in the field.

According to Saren and Pels (2008), CMP scientific production may have well contributed to expanding the knowledge of how companies relate to their markets, as it highlights the relevance of marketing and CMP in the organizational settings.

\section{Methodology}

This research began with a bibliographical survey, which was devised to identify the extant contemporary marketing practices studies in international outlets, ranging from the first publication in 1997 through December 2016.

We adopted a mixed, descriptive methods approach. The research is exploratory in nature, since our objective is to characterize the scientific CMP production from the selected sources. Having said that, we note that our findings cannot be considered conclusive and that they cannot not be generalized (RICHARDSON, 2008). Per Creswell and Creswell's (2017) concept, the combined choice of qualitative (i.e., data collection as well as the selected bibliographic portfolio) and quantitative methods (for analysis of the selected documents and the interpretation of the information) characterizes a mixed method approach. The study seeks to describe and classify the bulk of international scientific production from the selected bibliographic sources.

Following Creswell and Creswell's (2017) recommendation, we performed a documentary survey of extant CMP research from January to February, 2017. We selected studies containing the descriptors (keywords, singular or plural), that contained "contemporary marketing practice" and "contemporary 
marketing strategy". We then searched the EBSCO, SCOPUS, Spell / Anpad and Google Scholar databases and selected the Applied Social Sciences and Marketing fields. Our requirement was that articles should be published in a journal, with a document available in full text format that could be retrieved.

Initially, we found 126 documents that could potentially meet these criteria, and subsequently submitted them to a refinement process to verify their alignment with our research objectives. Of these, 57 documents were non-academic documents, duplicate or restricted access documents which were excluded from the sample. The remaining 69 documents were analyzed; when the document title, abstract and keywords were not aligned with our subject, the paper was dropped. Books, book chapters and other publications such as dissertations and thesis were eliminated as well, yielding a total of 50 articles.

This subset of bibliographic studies was read in full, but only 42 complied with our research objectives, and an article published in a congress was dropped. Figure 1 summarizes the process of refinement of the CMP research, leading to the final bibliographic portfolio.

Figure 1 - Refinement process and selection of the bibliographic research portfolio.

\begin{tabular}{|c|c|c|c|c|}
\hline $\begin{array}{c}126 \\
\text { documents }\end{array}$ & $\begin{array}{c}69 \\
\text { documents }\end{array}$ & $\begin{array}{c}57 \\
\text { studies }\end{array}$ & $\begin{array}{c}\mathbf{5 0} \\
\text { studies }\end{array}$ & $\begin{array}{c}42 \text { studies } \\
41 \text { scientific articles } \\
1 \text { congress articles }\end{array}$ \\
\hline $\begin{array}{l}\text { Result of initial } \\
\text { query in databases }\end{array}$ & $\begin{array}{l}\text { Result after } \\
\text { elimination of non- } \\
\text { academic, repeated } \\
\text { and restricted access } \\
\text { studies }\end{array}$ & $\begin{array}{l}\text { Result after } \\
\text { elimination of } \\
\text { studies not aligned } \\
\text { with titles and } \\
\text { keywords. }\end{array}$ & $\begin{array}{l}\text { Result after } \\
\text { elimination of books } \\
\text { / chapters and } \\
\text { studies not fully } \\
\text { related to } \\
\text { contemporary } \\
\text { marketing practices. }\end{array}$ & $\begin{array}{l}\text { Result after more in- } \\
\text { depth reading of } \\
\text { summary, introduction, } \\
\text { theoretical reference } \\
\text { and final } \\
\text { considerations. } \\
\text { Non-repeating articles } \\
\text { with book access and } \\
\text { fully aligned with the } \\
\text { research topic. }\end{array}$ \\
\hline
\end{tabular}

Source: Prepared by the Authors (2018).

Following that, we conducted a content analysis to produce a thematic categorization in the reading, selection and classification of the data from the bibliographic portfolio. Table 2 depicts the information categories, in line with the conceptual definitions of Sarquis et al. (2016).

Table 2 - Data categories used in the process of analysis

\begin{tabular}{|c|c|c|}
\hline Category & Subcategory & Description \\
\hline \multirow{5}{*}{ Paper information } & Title & Identify the title \\
\hline & Author & Identify the author \\
\hline & Publication year & Identify the year of publication \\
\hline & Relevance & Identify the relevance \\
\hline & Keywords & Identify the keywords \\
\hline \multirow{3}{*}{$\begin{array}{l}\text { Place of study and } \\
\text { publication }\end{array}$} & & $\begin{array}{l}\text { Identify the scientific publication where the paper was } \\
\text { published }\end{array}$ \\
\hline & University & Identify the universities that participated in the study \\
\hline & Country & Identify the countries that participated in the study \\
\hline \multirow{5}{*}{ Research methods } & Approach & Identify the approach of the research \\
\hline & Nature of the research & Identify the nature of the research \\
\hline & Research strategy & Identify the research strategy \\
\hline & Data collection method & Identify the data collection method \\
\hline & Analytical technique & Identify the analytical technique \\
\hline
\end{tabular}

Source: Prepared by the Authors (2018). 
The ensuing analysis of the selected bibliographic portfolio is predicated on the following laws of bibliometrics: Lotka's Law, Zipf's Law, and Bradfort's Law. According to Guedes and Borschiver (2005), these are some of the most widely used laws in the Business Administration area.

The Law of Lotka deals with the productivity of researchers; the author proposes that a restricted number of researchers will have more relevant scientific contributions in a given timeframe. Conversely, Zipf's Law deals with the relationship between the position of a term, and its frequency of appearance in a set of documents; the author proposes that the position of a word in an ordered list is inversely proportional to its frequency of appearance. Finally, in the context of a given topic, Bradford Law posits that there will be a limited number of scientific outlets that publish many articles, and that several journals will only publish a limited number of papers in a given time period (BOGAERT; ROUSSEAU; VAN HECKE, 2000).

\section{Presentation and Analysis or Results}

In this section, we describe the selected bibliographic portfolio and the key characteristics of the international scientific CMP production. Table 3 depicts the bibliographic portfolio selected with the 42 studies, by year of publication. 
Table 3 - Bibliographic portfolio of the contemporary marketing practices theme.

\begin{tabular}{|c|c|c|}
\hline Title & Author & Year \\
\hline Understanding contemporary marketing: development of a classification scheme & $\begin{array}{l}\text { Coviello, N.; Brodie, R.; Munro, } \\
\text { H. }\end{array}$ & 1997 \\
\hline $\begin{array}{l}\text { An exploration of contemporary marketing practices in the New Zealand wine sector: evidence from three } \\
\text { cases }\end{array}$ & Lindgreen, A. & 2001 \\
\hline Contemporary marketing practices of consumer and business-to-business firms: how different are they? & Coviello, N.; Brodie, R. & 2001 \\
\hline Understanding IT-enabled interactivity in contemporary marketing & $\begin{array}{l}\text { Coviello, N.; Milley, R.; Marcolin, } \\
\text { B. }\end{array}$ & 2001 \\
\hline How firms relate to their markets: an empirical examination of contemporary marketing practices & Coviello et al. & 2002 \\
\hline $\begin{array}{l}\text { Integrating information technology into marketing practice - the IT reality of contemporary marketing } \\
\text { practice }\end{array}$ & Brady, M.; Saren, M.; Tzokas, N. & 2002 \\
\hline Assessing the role of e-Marketing in contemporary marketing practice & Coviello et al. & 2003 \\
\hline Marketing practice and market orientation: an exploratory international study & Palmer, R.; Pels, J. & 2004 \\
\hline Profiling marketing practice in an emerging economy: the Argentine case & Pels, J.; Brodie, R. & 2004 \\
\hline What are they doing? a study of contemporary marketing practice in Ireland & Brady, M.; Palmer, R. & 2004 \\
\hline Contemporary marketing practices in Russia & Wagner, R. & 2005 \\
\hline $\begin{array}{l}\text { How managers perceive the impacts of information technologies on contemporary marketing practices: } \\
\text { reinforcing, enhancing or transforming? }\end{array}$ & Brookes et al. & 2005 \\
\hline Relationships within the supply chain: a case study & $\begin{array}{l}\text { Lindgreen, A.; Palmer, R.; } \\
\text { Trienekens, J. }\end{array}$ & 2005 \\
\hline The 'real thing': branding authenticity in the luxury wine trade & Beverland, $\mathrm{M}$. & 2006 \\
\hline $\begin{array}{l}\text { The application of stakeholder theory to relationship marketing strategy de velopment in a non-profit } \\
\text { organization }\end{array}$ & Knox, S.; Gruar, C. & 2007 \\
\hline The service-dominant logic of marketing: a logical and evidential case for multiple logics? & Brookes, R. & 2007 \\
\hline A comment on paradox and middle-range theory: universality, synthesis and supplement & Saren, M.; Pels, J. & 2008 \\
\hline Business-to-business marketing practices in West Africa, Argentina and the United States & Dadzie, K.; Johnston, W.; Pels, J. & 2008 \\
\hline Contemporary marketing in professional services & Reid, M. & 2008 \\
\hline Contemporary marketing practices research program: a review of the first decade & $\begin{array}{l}\text { Brodie, R.; Coviello, N; } \\
\text { Winklhofer, H. }\end{array}$ & 2008 \\
\hline Do different marketing practices require different leadership styles? an exploratory study & Lindgreen et al. & 2008 \\
\hline Exploring paradox in marketing: managing ambiguity towards synthesis & O'Driscoll, A. & 2008 \\
\hline Professional service firms are relationship marketers: but does size matter? & Mc Coll-Kennedy et al. & 2008 \\
\hline $\begin{array}{l}\text { Research-informed teaching and teaching-informed research: } \\
\text { the contemporary marketing practices(CMP) living case study approach to } \\
\text { understanding marketing practice }\end{array}$ & Little, V.; Brookes, R.; Palmer, R. & 2008 \\
\hline $\begin{array}{l}\text { Researching the role of information and communications technology (ICT) in contemporary marketing } \\
\text { practices }\end{array}$ & \begin{tabular}{|l|} 
Brady, M.; Fellenz, M.; Brookes, \\
R.
\end{tabular} & 2008 \\
\hline Social marketing: Implications for contemporary marketing practices classification scheme & Domegan, $\mathrm{C}$. & 2008 \\
\hline An exploratory case study analysis of contemporary marketing practices & Palmer, R.; Hugh, W.; & 2009 \\
\hline Contemporary marketing practices (CMP) in Indian retail banking & Das, K.; & 2009 \\
\hline Do we really understand business marketing? getting beyond the RM and BM matrimony & Pels, J.; Möller, K.; Saren, M. & 2009 \\
\hline How professional service firms compete in the market: an exploratory study & Amonini et al. & 2010 \\
\hline The marketing practices-performance relationship in professional service firms & $\begin{array}{l}\text { Sweeney, J.; Soutar, G.; } \\
\text { McColl-Kennedy, J. }\end{array}$ & 2011 \\
\hline Theorizing about the service dominant logic: the bridging role of middle range theory & Brodie, R.; Saren, M.; Pels, J. & 2011 \\
\hline The use of communication activities in the development of small to medium-sized enterprise brands & Centeno, E.; Hart, S. & 2012 \\
\hline Marketing practices, between transactions and relationships, of companies in Brazil & $\begin{array}{l}\text { Targino, L.; Urdan, A.; Chauvel, } \\
\text { M. }\end{array}$ & 2013 \\
\hline $\begin{array}{l}\text { Current marketing practices and market orientation in the context of an emerging economy: the case of } \\
\text { Uruguay }\end{array}$ & $\begin{array}{l}\text { Lado, N.; Duque, L.; Alvarez } \\
\text { Bassi, D. }\end{array}$ & 2013 \\
\hline Strategic brand orientation and its antecedents & Harrison-Walker, L. & 2014 \\
\hline Using discourse analysis in case study research in business-to-business contexts & Ellis, N.; Rod, M. & 2014 \\
\hline $\begin{array}{l}\text { Converging sustainable entrepreneurship and the contemporary marketing practices. an insight into } \\
\text { Romanian start-ups }\end{array}$ & Hapenciuc et al. & 2015 \\
\hline Exploring the brand's world-as-assemblage: the brand as a market shaping device & Onyas, W.; Ryan, A. & 2015 \\
\hline Information technology utilization for industrial marketing activities: the IT-marketing gap & $\begin{array}{l}\text { Ekman, P.; Erixon, C.; Thilenius, } \\
\text { P. }\end{array}$ & 2015 \\
\hline Marketing management of properties in rural tourism & Vujeva, V. & 2015 \\
\hline $\begin{array}{l}\text { Matching organizational frame of reference and business strategy with contemporary marketing pract } \\
\text { evidence from Arab world }\end{array}$ & Farha, A. & 2016 \\
\hline
\end{tabular}

Source: Prepared by the Authors (2018). 
Figure 2 shows the evolution of the published CMP research as of 2016. The first article was published by Coviello, Brodie and Munro (1997). With respect to the number of published studies, ten articles were published in 2008, and four articles were published in 2015. In 2001, 2004, 2005 and 2009, there were three articles published each year; in 2002, 2007, 2011, 2013 and 2014, only two articles per year were published. Accordingly, the annual average of international scientific CMP production is 2.1 articles per year. We thus conclude that international scientific production remains relatively stable since 2001; on the other hand, the production is scarce, which translates to the need to expand this stream of research.

Figure 2 - Trend of published scientific work through 2016.

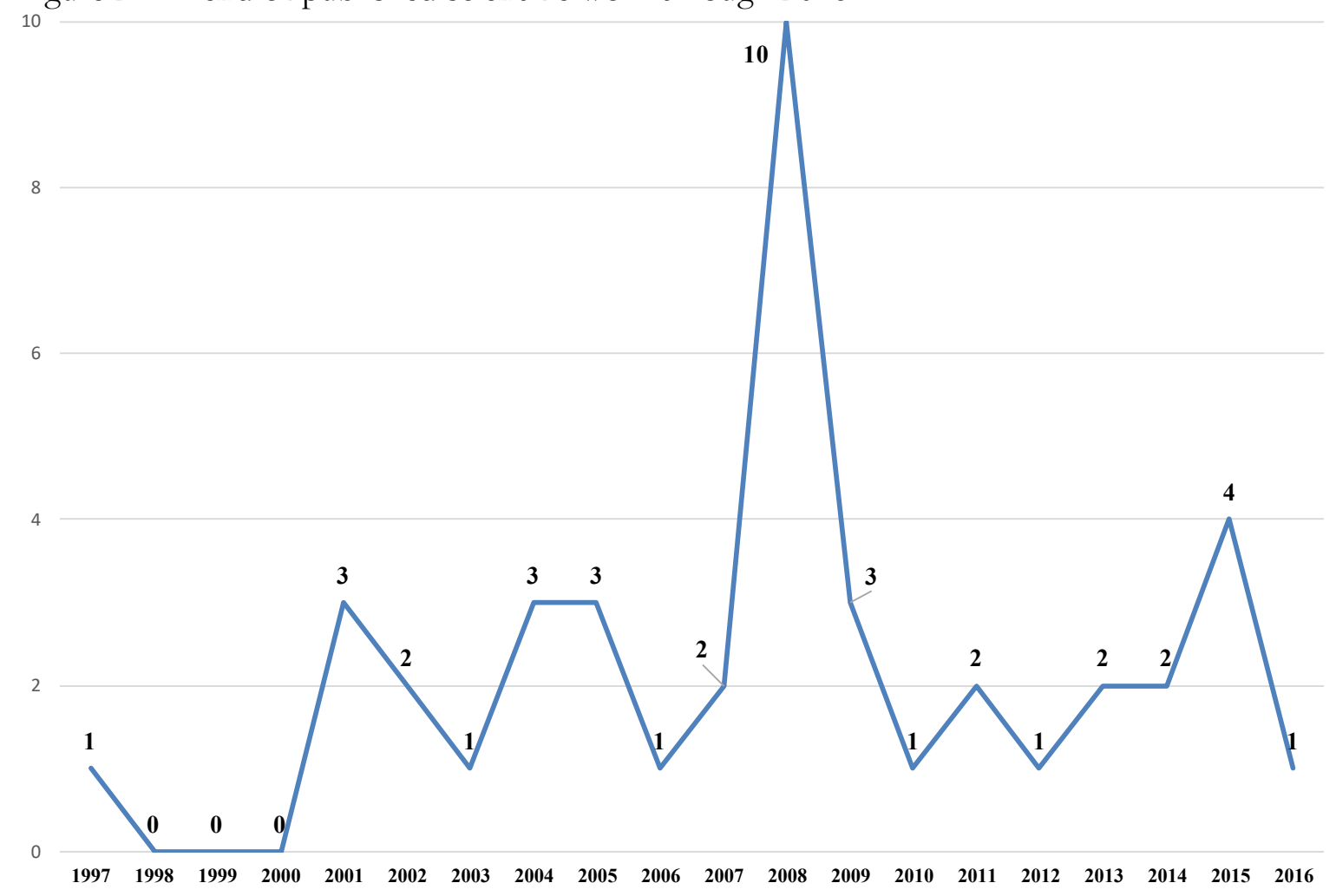

Source: Prepared by the Authors (2018).

Table 4 depicts the list of the most relevant research per number of citations from the Google Scholar Citations website. On November 2, 2018, the average citations of published studies on the subject was 80.8 .

The above-average scientific production accounts for nearly a third of the published articles. 55\% of the total citations correspond to five published articles, including: Coviello et al. (2002), with 646 citations; Coviello, Brodie and Munro (1997), with 417; Beverland (2006), with 388; Coviello, Milley and Marcolin (2001), with 241; and Knox and Gruar (2007), with 184 citations.

Even though the number of papers is relatively small, we conclude that the scientific CMP production has achieved significance as a result of the high number of citations, which demonstrates their importance as a source of reference. 
Table 4 - Most relevant research, by number of citations in Google Scholar Citations.

\begin{tabular}{|c|c|c|c|}
\hline Title & Author & Amount & $\begin{array}{l}\text { \% of total } \\
\text { citations }\end{array}$ \\
\hline $\begin{array}{l}\text { How firms relate to their markets: an empirical examination of } \\
\text { contemporary marketing practices }\end{array}$ & Coviello et al. (2002) & 646 & $19 \%$ \\
\hline $\begin{array}{l}\text { Understanding contemporary marketing: development of a } \\
\text { classification scheme }\end{array}$ & $\begin{array}{l}\text { Coviello; Brodie e Munro } \\
\text { (1997) }\end{array}$ & 417 & $12 \%$ \\
\hline The 'real thing': branding authenticity in the luxury wine trade & Beverland (2006) & 388 & $11 \%$ \\
\hline Understanding IT-enabled interactivity in contemporary marketing & $\begin{array}{l}\text { Coviello; Milley e } \\
\text { Marcolin (2001) }\end{array}$ & 241 & $7 \%$ \\
\hline $\begin{array}{l}\text { The application of stakeholder theory to relationship marketing strategy } \\
\text { development in a non-profit organization }\end{array}$ & Knox e Gruar (2007) & 184 & $5 \%$ \\
\hline $\begin{array}{l}\text { Contemporary marketing practices of consumer and business-to- } \\
\text { business firms: how different are they? }\end{array}$ & Coviello e Brodie (2001) & 182 & $5 \%$ \\
\hline $\begin{array}{l}\text { Integrating information technology into marketing practice - the IT } \\
\text { reality of contemporary marketing practice }\end{array}$ & Brady et al. (2002) & 148 & $4 \%$ \\
\hline $\begin{array}{l}\text { Theorizing about the service dominant logic: the bridging role of } \\
\text { middle range theory }\end{array}$ & Brodie; Saren e Pels (2011) & 111 & $3 \%$ \\
\hline $\begin{array}{l}\text { Contemporary marketing practices research program: a review of the } \\
\text { first decade }\end{array}$ & $\begin{array}{l}\text { Brodie; Coviello e } \\
\text { Winklhofer (2008) }\end{array}$ & 89 & $3 \%$ \\
\hline $\begin{array}{l}\text { Researching the role of information and communications technology } \\
\text { (ICT) in contemporary marketing practices }\end{array}$ & $\begin{array}{l}\text { Brady; Fellenz e Brookes } \\
\text { (2008) }\end{array}$ & 86 & $3 \%$ \\
\hline
\end{tabular}

Source: Prepared by the Authors (2018).

It is worth mentioning that there are several outlets that publish CMP studies, among which: Journal of Marketing Management, Journal of Marketing, Journal of Interactive Marketing, Journal of Marketing Services and Journal of Marketing. There are eleven scientific journals with a high (greater than one) impact factor that publish CMP studies, such as: Journal of Service Management (JCR 3.927), Journal of Marketing (3.885), Journal of Interactive Marketing (3.256), Marketing Theory (2.673) and Journal of Business Research (2.129), among others. Hence, we conclude that many CMP studies were published in first-tier journals, which demonstrates that these articles have high impact and generate interest from the international scientific community. They also indicate that the extant research has advanced the knowledge in the field, and provide significant theoretical contribution; this would lead us to believe that the field has reached academic maturity (FENSTERSEIFER, 2003).

Table 5 presents the main scientific journals that publish CMP studies and their respective impact factors, according to the Journal Citation Reports (JCR). Only three journals published two or more papers: Journal of Business \& Industrial Marketing (with 11 articles; UK-based and published by Emerald Insight); Journal of Marketing Management (5 articles; UK-based and published by Taylor \& Francis Online); Australasian Marketing Journal (2 articles; Australia, published by Elsevier). According to Bradford's Law, the core outlets for CMP research is composed of few scientific journals (only three). The remainder of the journals only published one single article each during that period. 
Table 5 - Key periodicals that published CMP research.

\begin{tabular}{|c|c|c|c|c|}
\hline Journal & Country & (JCR) & Amount & $\%$ \\
\hline Journal of Business \& Industrial Marketing & U.K. & 0.973 & 11 & $26.83 \%$ \\
\hline Journal of Marketing Management & U.K. & 1.81 & 5 & $12.2 \%$ \\
\hline Australasian Marketing Journal & Australia & 0.643 & 2 & $4.88 \%$ \\
\hline Journal of Service Management & U.K. & 3.927 & 1 & $2.44 \%$ \\
\hline Journal of Marketing & USA & 3.885 & 1 & $2.44 \%$ \\
\hline Journal of Interactive Marketing & USA & 3.256 & 1 & $2.44 \%$ \\
\hline Marketing Theory & U.K. & 2.673 & 1 & $2.44 \%$ \\
\hline Journal of Business Research & USA & 2.129 & 1 & $2.44 \%$ \\
\hline Journal of Small Business Management & U.K. & 1.937 & 1 & $2.44 \%$ \\
\hline Journal of Business Ethics & Netherlands & 1.837 & 1 & $2.44 \%$ \\
\hline Marketing Intelligence and Planning & U.K. & 1.44 & 1 & $2.44 \%$ \\
\hline Journal of Services Marketing & U.K. & 1.021 & 1 & $2.44 \%$ \\
\hline European Journal of Marketing & U.K. & 1.088 & 1 & $2.44 \%$ \\
\hline Journal of Relationship Marketing & USA & 0.900 & 1 & $2.44 \%$ \\
\hline Journal of Marketing \& Communication & U.K. & 0.618 & 1 & $2.44 \%$ \\
\hline Amfiteatru Economic & Romenia & 0.564 & 1 & $2.44 \%$ \\
\hline Journal of Strategic Marketing & U.K. & 0.393 & 1 & $2.44 \%$ \\
\hline Academy of Marketing Studies Journal & USA & 0.33 & 1 & $2.44 \%$ \\
\hline Journal on Chain and Network Science & Netherlands & 0.279 & 1 & $2.44 \%$ \\
\hline Journal of Euromarketing & USA & 0.26 & 1 & $2.44 \%$ \\
\hline Journal of Global Marketing & USA & 0.235 & 1 & $2.44 \%$ \\
\hline Brazilian Business Review & Brazil & - & 1 & $2.44 \%$ \\
\hline International Journal of Emerging Markets & U.K. & - & 1 & $2.44 \%$ \\
\hline International Journal of Wine Marketing & U.K. & - & 1 & $2.44 \%$ \\
\hline
\end{tabular}

Source: Prepared by the Authors (2018).

Figure 3 depicts the network of authors of the extant research from the selected bibliographic portfolio, using the VOSviewer software. The figure demonstrates that there are twelve networks of researchers; yet, most contain few (two or three) members. One possible explanation is that a significant part of the authors published few papers during that timeframe. Of the 56 researchers that published articles, only eleven published more than two, and only six published more than three CMP articles: Palmer (8), Brodie (8), Coviello (7), Pels (6), Brookes 5) and Saren (4). This outcome corroborates Lotka's Law, which stipulates that a small number of researchers will publish many articles, while several others publish a few. As Guedes and Borschiver (2005) state, such concentration of research indicates that the subject is still being developed as a field of knowledge - though it may be argued that there is a consistent production in high impact scientific outlets, as previously shown. 


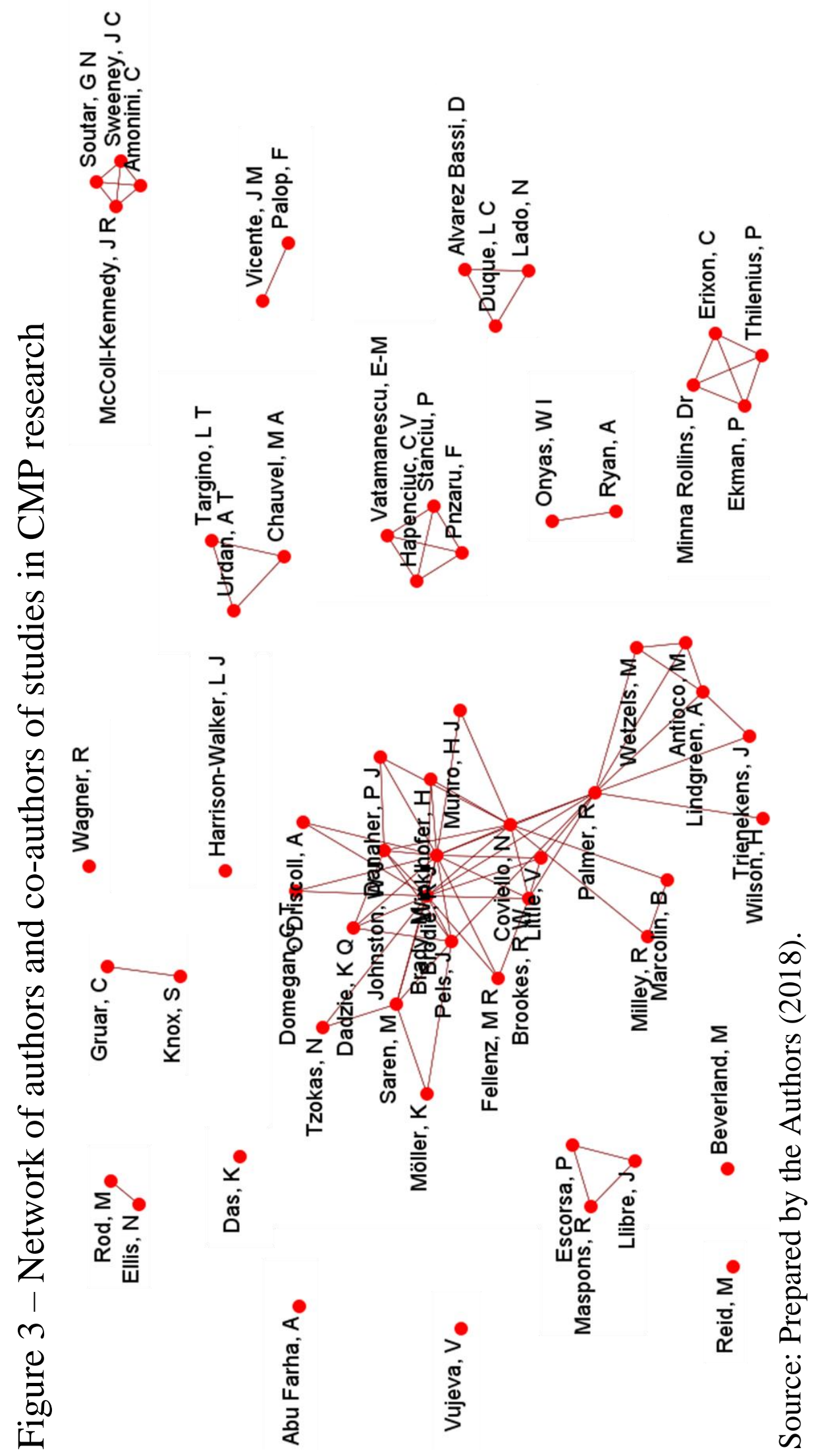


Figure 4 provides a detailed description of the main CMP research network, encompassing the largest number of researchers $(27$ members) and the largest number of CMP research published in this period (21 articles). This includes Brady, Brodie, Palmer and Coviello, the pioneering researchers from the Contemporary Marketing Practices group from the Auckland University in New Zealand.

Figure 4 - Main network of authors and co-authors of CMP research.

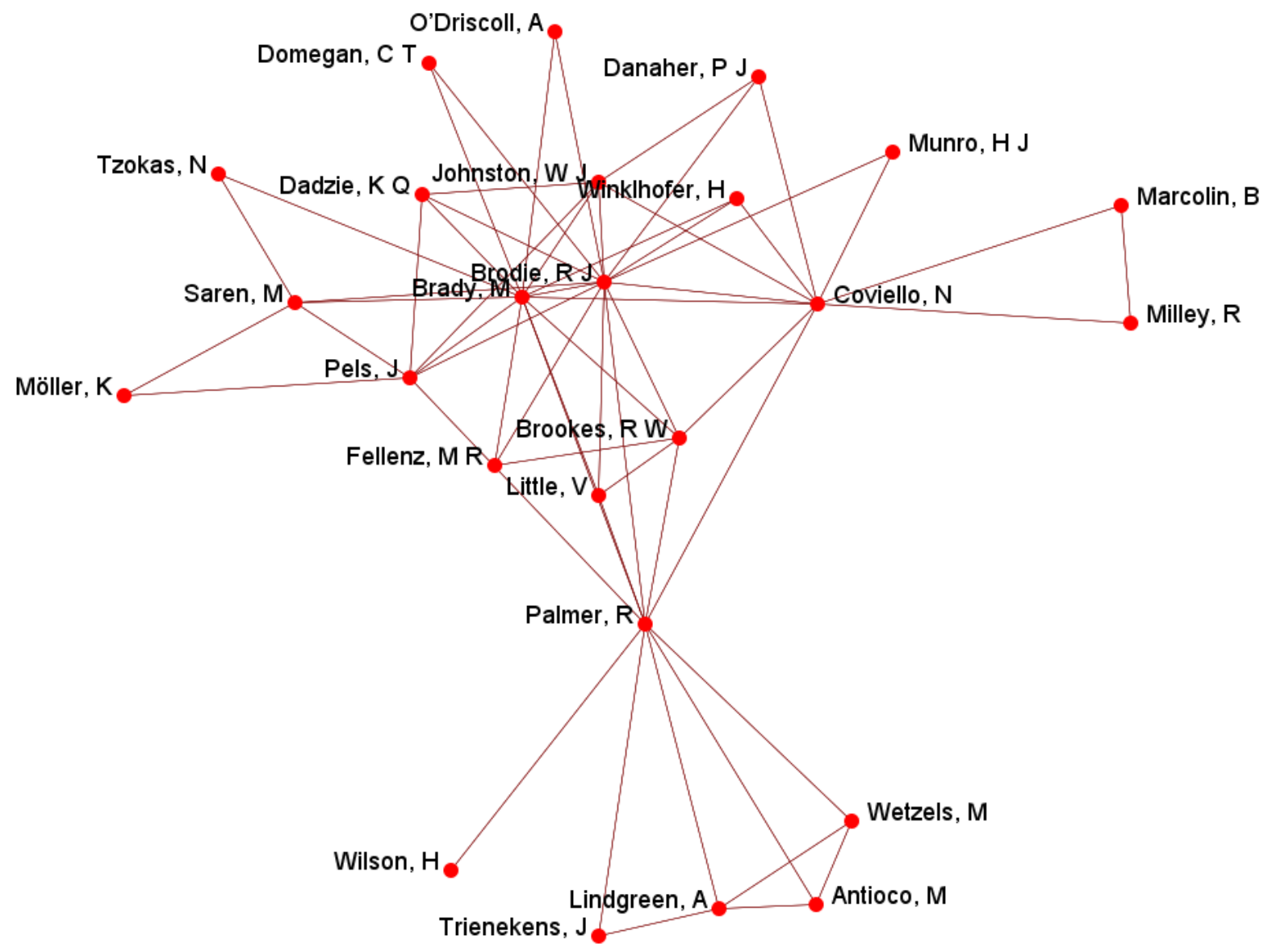

Source: Prepared by the Authors (2018).

With respect to the universities that publish CMP research, our findings indicate that $50 \%$ of the research comes from nine organizations: University of Auckland (New Zealand), University of Western Australia (Australia), University of Queensland (Australia), University of Calgary (Canada), Georgia State University (USA), Henley Management College (United Kingdom), Torcuato Di Tella University (Argentina), WA Business School University of Western Australia, and Cranfield School of Management. Considering the total of 49 institutions, half of them published only one CMP scientific article during this period.

Figure 5 shows the tag cloud of the most frequent words in published research, using the Word Clouds software. The selected bibliographic works contain 113 keywords, and those unrelated to CMP were dropped. We grouped keywords that had similar meaning (for instance, brand and branding, marketing practices and marketing practices, and so forth). The most frequently cited words are: relationship marketing (11.5\% of the papers), marketing strategy $(8,8 \%)$, contemporary marketing practices $(7.1 \%)$, marketing practices $(7.1 \%)$, and interaction marketing $(4.4 \%)$. In contrast, the less cited words (but which were considered useful CMP descriptors) are: brand / branding, professional services, B2B marketing, database marketing, information technology, network marketing, communication technologies and transaction marketing. Hence, as Zipf's Law suggests, we find evidence of relationships 
between the frequency of the word and its relative position in terms of citations in CMP research, which leads us to the conclusion that there are some words that are frequently used, and several others that are seldom used.

Figure 5 - Tag cloud of the most frequently used words in CMP research.

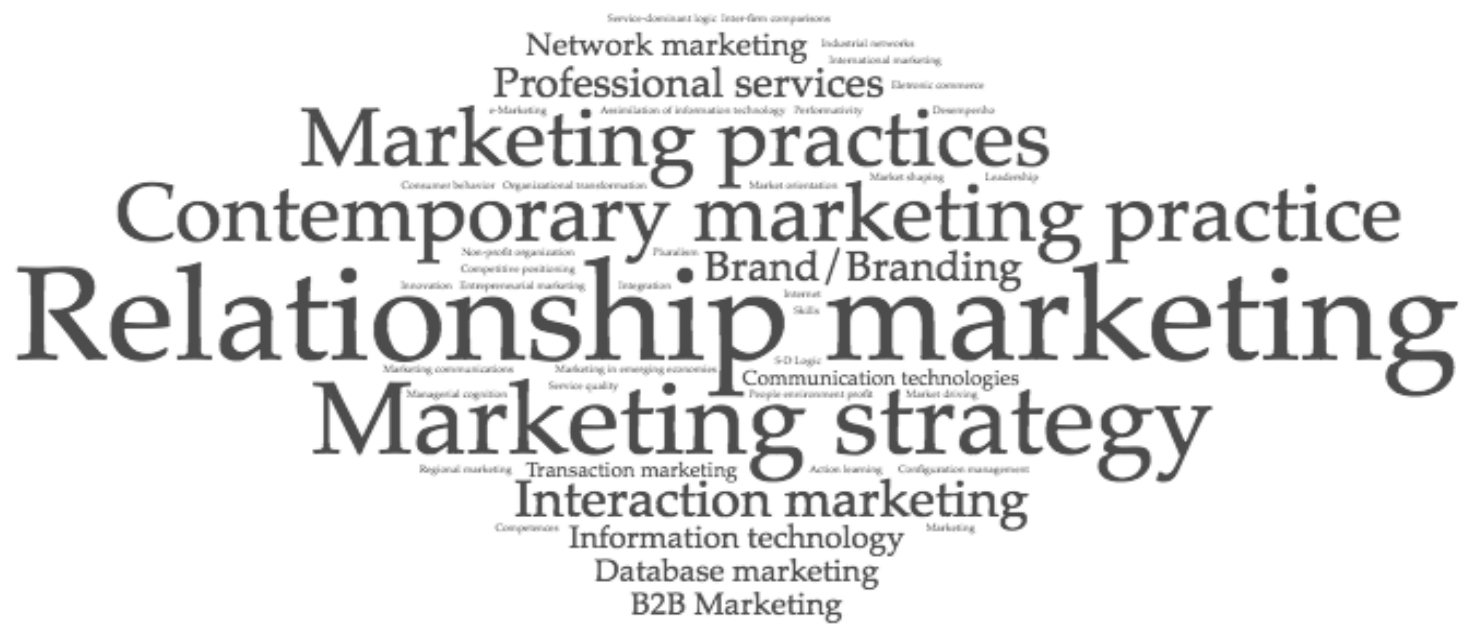

Source: Prepared by the Authors (2018).

Lastly, Table 6 depicts the methodological aspects of the extant CMP research. Our findings suggest that most studies use a qualitative approach (55\% of the studies) and are empirical (76\%). The predominance of qualitative studies indicates that the CMP research is still in an exploratory stage, since it seeks to broaden the understanding or deepen the knowledge on the theme. Of the 42 articles published, ten are theoretical studies; this is typically the case when the subject is not yet considered mature, since it still requires theoretical discussions and further analysis regarding its fundamental concepts, practices and propositions.

Table 6 - Methodological aspects of CMP extant research.

\begin{tabular}{|c|c|c|c|c|c|}
\hline Approach of studies & Amount & $\%$ & Data analysis technique & Amount & $\%$ \\
\hline Qualitative & 23 & $55 \%$ & Content analysis & 15 & $24 \%$ \\
\hline Quantitative & 13 & $31 \%$ & Cluster Analysis & 11 & $17 \%$ \\
\hline Mixed & 6 & $14 \%$ & Regression analysis & 8 & $13 \%$ \\
\hline Nature of studies & Amount & $\%$ & Cross-case analysis & 4 & $6 \%$ \\
\hline Empirical research & 32 & $76 \%$ & Factor analysis & 4 & $6 \%$ \\
\hline Theoretical approach & 10 & $24 \%$ & Correlation analysis & 3 & $5 \%$ \\
\hline Data collection technique & Amount & $\%$ & Analysis of covariance & 2 & $3 \%$ \\
\hline Survey & 18 & $41 \%$ & Analysis of variance and Manova & 2 & $3 \%$ \\
\hline Interview & 12 & $27 \%$ & Within-case analysis & 2 & $3 \%$ \\
\hline Documentary survey & 10 & $23 \%$ & Canonical analysis & 2 & $3 \%$ \\
\hline Participant observation & 3 & $7 \%$ & Structural modeling modeling & 2 & $3 \%$ \\
\hline Not identified & 1 & $2 \%$ & Not identified & 8 & $13 \%$ \\
\hline
\end{tabular}

Source: Prepared by the Authors (2018).

With regards to data collection, $41 \%$ of the papers used surveys and questionnaires; $27 \%$ of used in-depth interviews; and 23\% were document-related. The most used data analysis techniques are: 
content analysis (24\% of the studies), cluster analysis (17\%), and linear or multivariate regression analysis $(13 \%)$. As pointed out by Venâncio, Andrade and Fiates (2014), the quality of the research is impaired when the research does not clearly identify the data collection and analysis techniques chosen.

\section{Proposal for a research agenda}

Based on our findings which emanate from the selected portfolio, a research agenda is hereby proposed to guide and direct future CMP work. As McColl-Kennedy et al. (2008) and Targino, Urdan and Chauvel (2013) indicate, there is a vital need to expand research work in the field - and even more so in Brazil. This study shows that the annual average of articles published is below par, and that the number of researchers with multiple CMP studies is minimal. In Brazil, one single article was published by Targino, Urdan and Chauvel (2013). Thus, a research agenda on an international level provides an important contribution and a stimulus for future CMP research.

With respect to database marketing, there is a need for studies that verify the impact of specific database marketing tools on business performance. Specifically, researchers and practitioners need to determine the aspects of transactions, sales processes and long-term relationship effects with clients and other relevant stakeholders. There is also a need to develop theoretical models that define the database management process in the context of small and medium-sized companies. Along these lines, Brodie, Coviello and Winklhofer (2008) indicate that there is a need to investigate the perception of practitioners with regards to the use of database and digital marketing.

Amonini et al. (2010) posit the need to analyze the impact of digital marketing practices on the company's customer relationship management. We believe there is a need to better appreciate the digital marketing processes, in order to identify possible hurdles and make its implementation more seamless. We must also examine the relationship between digital marketing and database marketing practices, and how one influences the performance of the other.

Centeno and Hart (2012) postulate the need for CMP research in the context of the company`s market orientation. The authors state that such studies will shed light on the impact of different contemporary marketing practices on brand performance and business communication strategies. Following Ekman, Erixon and Thilenius (2015) suggestions, we believe it is important to understand the role of information technology as it pertains to the digital marketing practices, and the impact of online social media on digital marketing.

With regards to interactive marketing, there are conceptual gaps with respect to the characteristics of consumers most interested in developing interpersonal relationships based on commitment, trust and cooperation (WARD; DAGGER, 2007), as well as a gap in the literature related to the cultural differences that affect the performance of interactive marketing practices (REID, 2008). Hence, new research could focus on the effectiveness of interactive marketing practices to identify the factors that affect the customer interaction process in certain sectors and industries - including B2B markets, as suggested by Theron and Terblanche (2010). The study by Wagner (2005) is one of the few articles that analyzes a specific context.

Regarding network marketing, Menelec and Jones (2015) posit the need to better understand small business practices, and Sweeney, Soutar and McColl-Kennedy (2011) postulate the need to identify performance metrics and develop measurement scales for network marketing performance. Along the same lines, we believe that the examination of the antecedents, factors of influence and consequent of network marketing is well justified, as well as the identification of the variables that render optimal performance results.

Thus, we conclude that CMP ought to be further studied in different sectors and branches of activities. The service sector is possibly the most studied; professional services, which includes institutions of higher learning, engineering, architecture, law and accounting services. Yet, there is a lack of knowledge in the fields of gastronomy, hotels, real estate, non-profit organizations, advertising 
agencies, medical hospitals and information technology. Along the same lines, few studies were carried out in the retail and consumer goods sectors (with the notable exception of the food industry). As Sweeney, Soutar, and McColl-Kennedy (2011) suggest, new research could analyze CMP in different sectors and industries, seeking to find similarities and differences with respect to marketing performance, and to understand the dimensions that impact most significantly the business performance.

Souza and Freitas (2016) also note the need to develop differentiated and innovative CMP research methods and techniques, since there is a prevalence of empirical, qualitative and exploratory studies. Our findings show that there is a lack of qualitative and quantitative studies that are conclusive and use experiments or a longitudinal approach. Lado, Duque, and Alvarez Bassi (2013) suggest that researchers analyze the developments in the contemporary marketing practice from the organizational perspective, and to look at long-term impact on performance. In addition, for the most part, studies used questionnaires, surveys, in-depth interviews and documentary surveys - methods that are deemed to be "traditional"). Future studies could use grounded theory, netnography, participant observation, Delphi panels, cognitive maps, experiments, and mixed methods. We also found few studies that employed advanced analytical techniques, such as structural equation modeling, confirmatory factor analysis, canonical correlation analysis, and other multivariate analytical methods. In the Brazilian context, the study of Brei, Mazzon, Farias and Matos (2016) corroborate this predominance of traditional analytical techniques.

Farha and Elbanna (2018) suggest that new CMP research using relationship tools be carried out. Specifically, such studies would use a management perspective in evaluating effectiveness and perceived value, with respect to the specific relationship practices of this body of theory. Other possible paths are studies that verify the existence of relationships between the organization and its stakeholders from the perspective of the use of CMP, as well as an in-depth exploration of the determinants of these relationships. Finally, while testing the effectiveness of marketing practice on performance is a valid perspective, the verification of other performance factors such as customer retention and satisfaction, market share, return on investment, and sales growth could also provide useful insights.

In conclusion, the conceptual model of CMP developed by Coviello, Brodie, and Munro (1997) and Coviello, Milley, and Marcolin (2001) that contains five dimensions needs to be updated to the current business environment. Although this model has been revised - with the inclusion of the digital marketing dimension -, its theoretical foundations demand continuous revision. In due course, the marketing approaches will need to be updated to maintain its relevance. Accordingly, future research could evaluate the fundamentals and principles of the CMP model to verify the need for new dimensions of marketing, which will facilitate the adaptation of the CMP components per their traits.

\section{Discussion}

Bibliometric studies measure the scientific production that pertains to a specific field of study, and help expand our knowledge of the phenomenon of interest (TEIXEIRA; IWAMOTO; MEDEIROS, 2013). This bibliographic study presents evidence of the international scientific Contemporary Marketing Practices production for the period ranging from 1996 to 2016. The last bibliographic CMP study was carried out by Brodie, Coviello and Winklhofer (2008) more than ten years ago. Hence, the present study provides an important update on the characteristics of the scientific production in the field, and expands our knowledge on the contemporary practices that firms use as they relate to the market.

Our findings indicate that there is a significant production in this period (42 papers), mainly related to the four dimensions of CMP posited by Coviello, Brodie and Munro (1997) and Coviello, Milley and Marcolin (2001), namely: database marketing, digital marketing, interaction marketing and network marketing. In addition, the production volume provides a clear indication that the CMP 
published research has continued since its inception in 1997, primarily as research papers in scientific journals.

The study also reveals the prevalence of twelve networks of CMP researchers, comprised of 101 authors of 49 Universities from various countries, including New Zealand, United Kingdom, Canada, Australia and the United States. The most productive network of CMP researchers is based in the College of Business Administration of the University of Auckland, in New Zealand. Our findings also reveal a significant body of knowledge, with academic quality and relevance, as shown by the number of citations in the literature (the selected bibliographic portfolio includes 2,694 citations). The research papers were published in specialized scientific journals, which have high impact factors - such as the Journal of Service Management, the Journal of Marketing, the Journal of Interactive Marketing, Marketing Theory and the Journal of Business Research. CMP research was published in 24 international scientific journals, most of them indexed in the Journal Citation Reports database (JCR).

In terms of research methods, the present study shows that most of the published papers adopted a qualitative approach; used case studies (either single or multiple cases); the data was collected through self-administered surveys or in-depth interviews; and that the most frequently used techniques were content analysis, cluster analysis and regression analysis. Considering these outcomes, we conclude that much of the CMP research has an exploratory nature, and it seeks to broaden or deepen our scientific knowledge of the subject (MISHRA et al., 2017). In addition, nearly one out of four of the papers that comprise the selected bibliographic portfolio are of a theoretical nature - in other words, they are essays, documentary research and literature review; this is expected when the theme has not reached maturity as a field of knowledge, and when the theme is still being discussed in terms of its concepts, dimensions, variables and specific interrelationships (LEONIDOU; LEONID, 2011).

The study also demonstrates that there is ample room for the development of empirical CMP research, as well as new research methods and analytical techniques. In the period analyzed, there was a modest average annual CMP research production, and knowledge is fragmented into specific perspectives and topics (such as relationship marketing, marketing strategy and branding). There are relatively few research networks that published more than two studies during this timeframe. There is a need to use advanced quantitative research methods in CMP research, specifically: using measurement scales; validating theoretical models; conducting experimental studies and longitudinal studies; and testing research hypotheses. Researchers such as Leonidou and Leonid (2011) and Mishra et al. (2017) consider that the use of advanced methods and techniques indicates the maturity of the field of knowledge.

The research gaps that arise from this study indicate the need to focus the research in the four dimensions of CMP, as posited by Coviello, Brodie and Munro (1997) and Coviello, Milley and Marcolin (2001). Such gaps lay out the direction of future paths for authors that seek to contribute for the evolution of contemporary marketing practices (MISHRA et al., 2017), specifically, those that pertain to the impact of specific database marketing in the firms' competitiveness (such as Big Data Analytics), the impact of specific digital marketing practices for customer engagement (such as online social media marketing), the impact of cultural differences in the interactive marketing performance and the identification of antecedents, moderating factors and consequents in network marketing. These directions are in line with the proposed framework by authors such as Reid (2008), Sweeney, Soutar and McColl-Kennedy (2011), Hapenciuc et al. (2015) and Ekman, Erixon and Thilenius (2015) for the development of the field.

In addition, CMP research must also be studied in different contexts: most of the extant research was carried out in the services sector and in the developed economies. Hence, there is a need to extend the SMP research in emerging economies (for instance, in Brazil only one single published work was found), small firms and startups, and specific sectors and business activities (such as retail consumer goods, manufactured products and non-profit organizations). There are also gaps in the production of CMP research in other relevant dimensions of current trends, such as sustainable marketing (GORDON; CARRIGAN; HASTINGS, 2011), experience marketing (SAME; LARIMO, 2012), sensorial marketing (HULTÉN, 2011), co-creation marketing (GUMMESSON; MELE, 2010), omnichannel marketing 
(PAYNE; PELTIER; BARGER, 2017) and human-centered marketing (KOTLER; KARTAJAYA; SETIAWAN, 2010 ).

Lastly, our findings produce evidence of an increasing scientific production of CMP research in the period analyzed, and even more so in recent years (2012 through 2015). This suggests that there is an increasing interest in CMP research, and this leads us to believe the research interest will occur chiefly in the dimensions of database marketing, digital marketing, interaction marketing and network marketing, since these areas tend to be more positively affected by the technological advances in the fields of Information Technology, Computer Engineering and Quantum computing, as well as an increased use of Big Data Analytics and Internet tools. In addition, the diverse scientific sources help disseminate the CMP research development, which is carried out in several Universities around the globe. The distribution of the scientific production will help foster the CMP awareness, and contribute for the consolidation of the theme as an independent field of knowledge (TEIXEIRA; IWAMOTO; MEDEIROS, 2013).

\section{Final considerations}

Bibliometric research plays an important role in understanding the collective knowledge of a particular field of study, and lays out an important foundation for relevant scientific studies (LEONIDOU; LEONID, 2011; MISHRA et al., 2017). This paper developed a bibliometric analysis of the international contemporary marketing practices in a twenty-year period, and in doing so a set of relevant authors, scientific journals, universities and countries that produced papers was identified, as well as the most prevalent research methods.

The research outcomes reveal the existence of a bibliographic portfolio comprised of dozens of scientific works that are fully aligned with the Contemporary Marketing Practices. This was produced by different authors from various research institutions, universities and countries. In addition, the research shows that the scientific CMP production is long-standing and that there are various papers with scientific quality and relevance. A significant number of international journals published papers, and there is a positive trend in the activity pertaining to the CMP research. The study describes in detail the network of researchers that are dedicated to CMP research, and provides insights related to scientific journals and authors. Our findings also reveal that in Brazil there is a gap in the availability of research work and authors, which corroborates the work of Mazzon and Hernandez (2013) in the services marketing area. Lastly, the study demonstrates that the extant research is mainly comprised of empirical, qualitative and exploratory research.

The study provides an important contribution for the proposition of a research agenda, by showing the existence of a gap in terms of the CMP dimensions, research methods and contextual settings. It also identifies promising research streams that are connect to the four CMP dimensions proposed by Coviello, Brodie and Munro (1997) and Coviello, Milley and Marcolin (2001), as well as other relevant and current trends and approaches. In doing so, it proposes new streams of research in diverse contexts (such as emerging economies, small firms and various sectors and branches of activity), as well as in the use of mixed methods research (qualitative and quantitative) of a conclusive and experimental nature, as well as longitudinal studies and the use of advanced statistical techniques for data analysis - such as structural equation modeling, confirmatory factor analysis and canonical correlation analysis. In this context, this study follows the recommendations laid out by Mazzon and Hernandez (2013), as it describes the research that has been published as well as the directions for future research work.

Another contribution of this study is the confirmation of the three classic laws of bibliometric studies: the laws of Lotka, Zipf and Bradfort. The research demonstrates that, in the period analyzed, there was a limited number of journals published papers on the theme, as posited by Bradford's law. According to Lotka's law, the core of the most productive authors that published CMP papers is still 
reduced. Lastly, per Zipf's law, there is a small number of keywords (search criteria) that is often used in the CMP research. In studies of a similar nature, the recommended approach is to follow these laws of bibliometric analysis (QUEVEDO-SILVA et al., 2016).

One key aspect emerges from the lack of studies of the extant international scientific production. The previous study by Brodie, Coviello and Winklhofer (2008) was published more than ten years ago, which analyzed the scientific production of the first decade (since the inception of the CMP concept). Thus, this study provides an update on the recent research, as well as the proposition of parameters that will help guide researchers and academic institutions interested in the theme. The bibliographic portfolio presented in this paper provides a theoretical foundation and relevant conceptual models in terms of hypothesis to be analyzed in future research.

In terms of the limitations of the study, the documentary survey comprises only manuscripts from four selected databases (EBSCO, SCOPUS, Spell/Anpad and Google Scholar); published in periodicals in the fields of Applied Social Sciences and Marketing; and with full text documents available in the CAPES journals link. The study focuses on the Contemporary Marketing Practices framework proposed by Coviello, Brodie and Munro (1997) and Coviello, Milley and Marcolin (2001). Consequently, the research only analyzes a fragment of the universal CMP research. Nonetheless, we strongly believe that the study stimulates the reflection and the development of new research, and contributes to the advancement of knowledge in the field.

Further bibliometric studies on the theme may confirm this study's outcomes, and may expand the knowledge of the status of the international scientific production. We suggest that the new studies include additional databases (such as Science Direct and Sage) and that they include the scientific production from dissertations, thesis and working papers. We also recommend that future studies be expanded to incorporate other dimensions of modern marketing practices, as suggested by Coviello, Brodie and Munro (1997) and Coviello, Milley and Marcolin (2001), as well as other relevant and current CMP dimensions, such as sustainable marketing, experiential marketing, sensorial marketing, co-creation marketing, omnichannel marketing, and human-centered marketing.

\section{References}

AMONINI, C.; MCCOLL-KENNEDY, J.; SOUTAR, G.; SWEENEY, J. How professional service firms compete in the market: an exploratory study. Journal of Marketing Management, v. 26, n. 1-2, p. 28-55, 2010.

BEVERLAND, M. The 'real thing': Branding authenticity in the luxury wine trade. Journal of Business Research, v. 59, n. 2, p. 251-258, 2006.

BOGAERT, J.; ROUSSEAU, R.; VAN HECKE, P. Percolation as a model for informetric distributions: fragment size distribution characterised by Bradford curves. Scientometrics, v. 47, n. 2, p. 195-206, 2000.

BREI, V.; MAZZON, J.; FARIAS, S.; MATOS, C. $1^{\circ}$ Censo Brasileiro dos Pesquisadores Acadêmicos de Marketing. Anais do EnANPAD, 2016.

BRODIE, R.; COVIELLO, N.; WINKLHOFER, H. Contemporary Marketing Practices research program: a review of the first decade. Journal of Business \& Industrial Marketing, v. 23, n. 2, p. 8494, 2008.

BRODIE, R.; WINKLHOFER, H.; COVIELLO, N.; JOHNSTON, W. Is e-marketing coming of age? An examination of the penetration of e-marketing and firm performance. Journal of Interactive Marketing, v. 21, n. 1, p. 2-21, 2007. 
CENTENO, E.; HART, S. The use of communication activities in the development of small to mediumsized enterprise brands. Marketing Intelligence \& Planning, v. 30, n. 2, p. 250-265, 2012.

COVIELLO, N.; BRODIE, R.; MUNRO, H. Understanding contemporary marketing: development of a classification scheme. Journal of Marketing Management, v. 13, n. 6, p. 501-522, 1997.

COVIELLO, N.; BRODIE, R. Contemporary marketing practices of consumer and business-to-business firms: how different are they? Journal of Business \& Industrial Marketing, v. 16, n. 5, p. 382-400, 2001.

COVIELLO, N.; MILLEY, R.; MARCOLIN, B. Understanding IT-enabled interactivity in contemporary marketing. Journal of Interactive Marketing, v. 15, n. 4, p. 18-33, 2001.

COVIELLO, N.; BRODIE, R.; DANAHER, P.; JOHNSTON, W. How firms relate to their markets: an empirical examination of contemporary marketing practices. Journal of Marketing, v. 66, n. 3, p. 3346, 2002.

COVIELlO, N.; BRODIE, R.; BROOKES, R.; PALMER, R. Assessing the role of e-marketing in contemporary marketing practice. Journal of Marketing Management, v. 19, n. 7-8, p. 857-881, 2003.

CRESWELL, J.; CRESWELL, J. Research design: Qualitative, quantitative, and mixed methods approaches. Sage publications, 2017.

EKMAN, P.; ERIXON, C.; THILENIUS, P. Information technology utilization for industrial marketing activities: the IT-marketing gap. Journal of Business \& Industrial Marketing, v. 30, n. 8, p. 926-938, 2015.

EL-GOHARY, H. E-Marketing: a literature review from a Small Businesses perspective. International Journal of Business and Social Science, v. 1, n. 1, p. 214-229, 2010.

FARHA, A.; ELBANNA, S. Do different marketing practices pre-suppose different frames of reference? An exploratory study. Journal of Business \& Industrial Marketing, v. 33, n. 3, p. 337-352, 2018.

FENSTERSEIFER, J. Comentários sobre em busca do conceito de linha de pesquisa e outras reflexões sobre o tema. Revista de Administração Contemporânea, v. 7, n. 2, p. 171-176, 2003.

GORDON, R.; CARRIGAN, M.; HASTINGS, G. A framework for sustainable marketing. Marketing theory, v. 11, n. 2, p. 143-163, 2011.

GREGUREC, I.; VRANEEVI, T.; DOBRINI, D. The importance of database marketing in social network advertising. International Journal of Management Cases, v. 13, n. 4, p. 165- 172, 2011.

GUEDES, V.; BORSCHIVER, S. Bibliometria: uma ferramenta estatística para a gestão da informação e do conhecimento, em sistemas de informação, de comunicação e de avaliação científica e tecnológica. CINFORM-Encontro Nacional de Ciência da Informação, v. 6, p. 1-18, 2005.

GUMMERUS, J.; VON KOSKULL, C.; KOWALKOWSKI, C. Guest editorial: Relationship marketing-Past, present and future. Journal of Services Marketing, v. 31, n. 1, p. 1-5, 2017.

GUMMESSON, E.; MELE, C. Marketing as value co-creation through network interaction and resource integration. Journal of Business Market Management, v. 4, n. 4, p. 181-198, 2010.

HULTÉN, B. Sensory marketing: the multi-sensory brand-experience concept. European Business Review, v. 23, n. 3, p. 256-273, 2011.

KOTLER, P.; KARTAJAYA, H.; SETIAWAN, I. Marketing 3.0: as forças que estão definindo o novo marketing centrado no ser humano. Elsevier, 2010. 
LADO, N.; DUQUE, L.; ALVAREZ BASSI, D. Current marketing practices and market orientation in the context of an emerging economy: the case of Uruguay. Journal of Small Business Management, v. 51, n. 4, p. 602-616, 2013.

LEONIDOU, C.; LEONIDOU, L. Research into environmental marketing/management: a bibliographic analysis. European Journal of Marketing, v. 45, n. 1/2, p. 68-103, 2011.

MARTÍNEZ-LÓPEZ, F.; MERIGÓ, J.; VALENZUELA-FERNÁNDEZ, L.; NICOLÁS, C. Fifty years of the European Journal of Marketing: a bibliometric analysis. European Journal of Marketing, v. 52, n. $1 / 2$, p. 439-468, 2018.

MAZZON, J.; HERNANDEZ, J. Produção científica brasileira em Marketing no período 2000-2009. Revista de Administração de Empresas (RAE), v. 53, n. 1, p. 67-80, 2013.

MCCOLL-KENNEDY, J.; SWEENEY, J.; SOUTAR, G.; AMONINI, C. Professional service firms are relationship marketers: but does size matter? Australasian Marketing Journal (AMJ), v. 16, n. 1, p. 3047, 2008.

MENELEC, V.; JONES, B. Networks and marketing in small professional service businesses. Journal of Research in Marketing and Entrepreneurship, v. 17, n. 2, p. 193- 211, 2015.

MISHRA, D.; LUO, Z.; JIANG, S.; PAPADOPOULOS, T.; DUBEY, R. A bibliographic study on big data: concepts, trends and challenges. Business Process Management Journal, v. 23, n. 3, p. 555-573, 2017.

NOBRE, H.; SILVA, D. Social network marketing strategy and SME strategy benefits. Journal of Transnational Management, v. 19, n. 2, p. 138-151, 2014.

O'DWYER, M.; GILMORE, A.; CARSON, D. Innovative marketing in SMEs. European Journal of Marketing, v. 43, n. 1, p. 46-61, 2009.

PAAS, L. Database marketing practices and opportunities in a newly emerging African market. Journal of Database Marketing \& Customer Strategy Management, v. 16, n. 2, p. 92-100, 2009.

PAYNE, E.; PELTIER, J.; BARGER, V. Omni-channel marketing, integrated marketing communications and consumer engagement: a research agenda. Journal of Research in Interactive Marketing, v. 11, n. 2, p. 185-197, 2017.

QUEVEDO-SILVA, F.; SANTOS, E.; BRANDÃO, M.; VILS, L. Estudo bibliométrico: orientações sobre sua aplicação. Revista Brasileira de Marketing, v. 15, n. 2, p. 246-262, 2016.

REID, M. Contemporary marketing in professional services. Journal of Services Marketing, v. 22, n. 5, p. 374-384, 2008.

RICHARDSON, R. Pesquisa social: métodos e técnicas. São Paulo: Atlas, 2008.

ROGAN, M.; MORS, M. Managerial networks and exploration in a professional service firm. Organization Studies, v. 38, n. 2, p. 225-249, 2017.

SACRAMENTO, P.; TEIXEIRA, R. Adoção de inovações em empresas de pequeno e médio porte: estudo de casos múltiplos em negócios hoteleiros na cidade de Aracaju. Revista Organizações em Contexto, v. 10, n. 19, p. 1-30, 2014.

SAME, S.; LARIMO, J. Marketing theory: experience marketing and experiential marketing. In: 7th International Scientific Conference Business and Management. 2012. p. 10-11. 
SAREN, M.; PELS, J. A comment on paradox and middle-range theory: universality, synthesis and supplement. Journal of Business \& Industrial Marketing, v. 23, n. 2, p. 105- 107, 2008.

SARQUIS, A.; CITTADIN, J.; DE MORAIS, A.; TONDOLO, R.; SANTOS, E. O estado da arte do tema marketing para pequenas empresas: um estudo bibliométrico da produção científica nacional. Revista Brasileira de Gestão e Inovação, v. 3, n. 3, p. 109-134, 2016.

SHAW, E.; JONES, D. A history of schools of marketing thought. Marketing theory, v. 5, n. 3, p. 239281, 2005.

SOUZA, L.; FREITAS, A. Revisão da produção científica brasileira em segmentação de mercado. Revista de Ciências da Administração, v. 1, n. 2, p. 96-108, 2016.

SWEENEY, J.; SOUTAR, G.; MCCOLL-KENNEDY, J. The marketing practices-performance relationship in professional service firms. Journal of Service Management, v. 22, n. 3, p. 292-316, 2011.

TARGINO, L.; URDAN, A.; CHAUVEL, M. As Práticas de marketing, entre transações e relacionamentos, de empresas no Brasil. Brazilian Business Review (BBR), v. 10, n. 2, p. 124-141, 2013.

TEIXEIRA, M.; IWAMOTO, H.; MEDEIROS, A. Estudos bibliométricos em administração: discutindo a transposição de finalidade. Administração: Ensino e Pesquisa, v. 14, n. 3, p. 423-452, 2013.

VENÂNCIO, D.; ANDRADE, D.; FIATES, G. Inovação em serviços: um estudo bibliométrico da produção científica no Portal Capes até setembro de 2013. Revista Eletrônica de Estratégia \& Negócios, v. 7, n. 1, p. 137-157, 2014.

WAGNER, R. Contemporary marketing practices in Russia. European Journal of Marketing, v. 39, n. 1, p. 199-215, 2005.

WILKIE, W.; MOORE, E. Scholarly research in marketing: exploring the "4 eras" of thought development. Journal of Public Policy \& Marketing, v. 22, n. 2, p. 116-146, 2003. 